\title{
SEASONAL VARIATION OF CARBOHYDRATE CONTENT IN STEM AND LEAVES OF ALMOND (PRUNUS AMYGDALUS L.)
}

\author{
Aysel Sivaci* and Sevcan Duman ${ }^{1}$ \\ Department of Biology, Art and Science Faculty, Adiyaman University, Adiyaman, Turkey
}

Key words: Almond, Carbohydrates, Ferragnes, Texas, Nonpareil, Seasonal

\begin{abstract}
Seasonal change of total carbohydrate contents in samples taken from leaves and stems of almond varieties was investigated. Carbohydrate contents in the leaves and stem of all varieties showed seasonal differences. The highest carbohydrate content in the leaves and stem of all varieties was found in April, and January, respectively. The lowest carbohydrate content in the leaves of Nonpareil was found in July, that of Ferragnes and Texas in October. The lowest level of carbohydrate content in the stem of all varieties was found in July.
\end{abstract}

Almond is a significant fruit tree growing all regions with Mediterranean climate having importance in terms of both nutritional and medical properties (Agunbiade and Olanlakun 2006, Misırlı and Gülcan 2000, Dokuzoğuz and Gülcan 1973). Seasonal variations in temperature, day length, precipitation, moisture, and wind affect reproductive and physiological processes in plants (Forshey and Elfving 1989, Gur 1985). Carbohydrate reserves in almond trees is a factor limiting the development in early spring; and the fact that carbohydrate reserves decrease due to decrease in photosynthesis in case of drought (Esparza et al. 2001). Determination of carbohydrate contents in almond varieties depending on changing climatic conditions may be important in terms of growing these plants, continuity and product yield. The objective of this study was to investigate the seasonal carbohydrate variations in leaves and stem of Nonpareil, Ferragnes and Texas varieties grown of almond (Prunus amygdalus L.) in Adiyaman/Turkey.

Samples were taken from the stem (April, July, October, January) and leaves (April, July, October) from three varieties namely, Nonpareil, Ferragnes and Texas of almond grown in village Lokman of Adiyaman, Turkey between 2011 and 2012. January, no sampling was made since the plants did not have the leaves. Average meteorological conditions in sampling periods were as follows; in April, temperature, $13.9^{\circ} \mathrm{C}$; humidity, $63.8 \%$; total rainfall $119.2 \mathrm{~mm}$, in July, temperature, $32.2^{\circ} \mathrm{C}$; humidity, $22.1 \%$; total rainfall $1.1 \mathrm{~mm}$, in October, temperature, $17.7^{\circ} \mathrm{C}$; humidity, $40.1 \%$; total rainfall $40.8 \mathrm{~mm}$ and in January, temperature, $3.7^{\circ} \mathrm{C}$; humidity, $77.8 \%$; total rainfall $333.5 \mathrm{~mm}$.

Fresh leaf and stem samples were dried for $48 \mathrm{hrs}$ at $70^{\circ} \mathrm{C}$. Total carbohydrate was extracted according to McCready et al. (1950). Total carbohydrate content were determined depending on standard glucose equivalence by reading their absorbance at 625 and $630 \mathrm{~nm}$ (Ebell 1969, McCready et al. 1950).

The data obtained from three replications of all treatments was subjected to the analysis of variance using SPSS 15.0 for Windows. Duncan's test was used for significance control $(p<0.05)$ following variance analysis.

The highest level of carbohydrate contents in leaves and stems of all three almond varieties were recorded in April and January, respectively (Fig. 1). The lowest carbohydrate content in the

*Author for correspondence: <asivaci@gmail.com>. ${ }^{1}$ Graduate School of Sciences, Adiyaman University, Adiyaman, Turkey. 


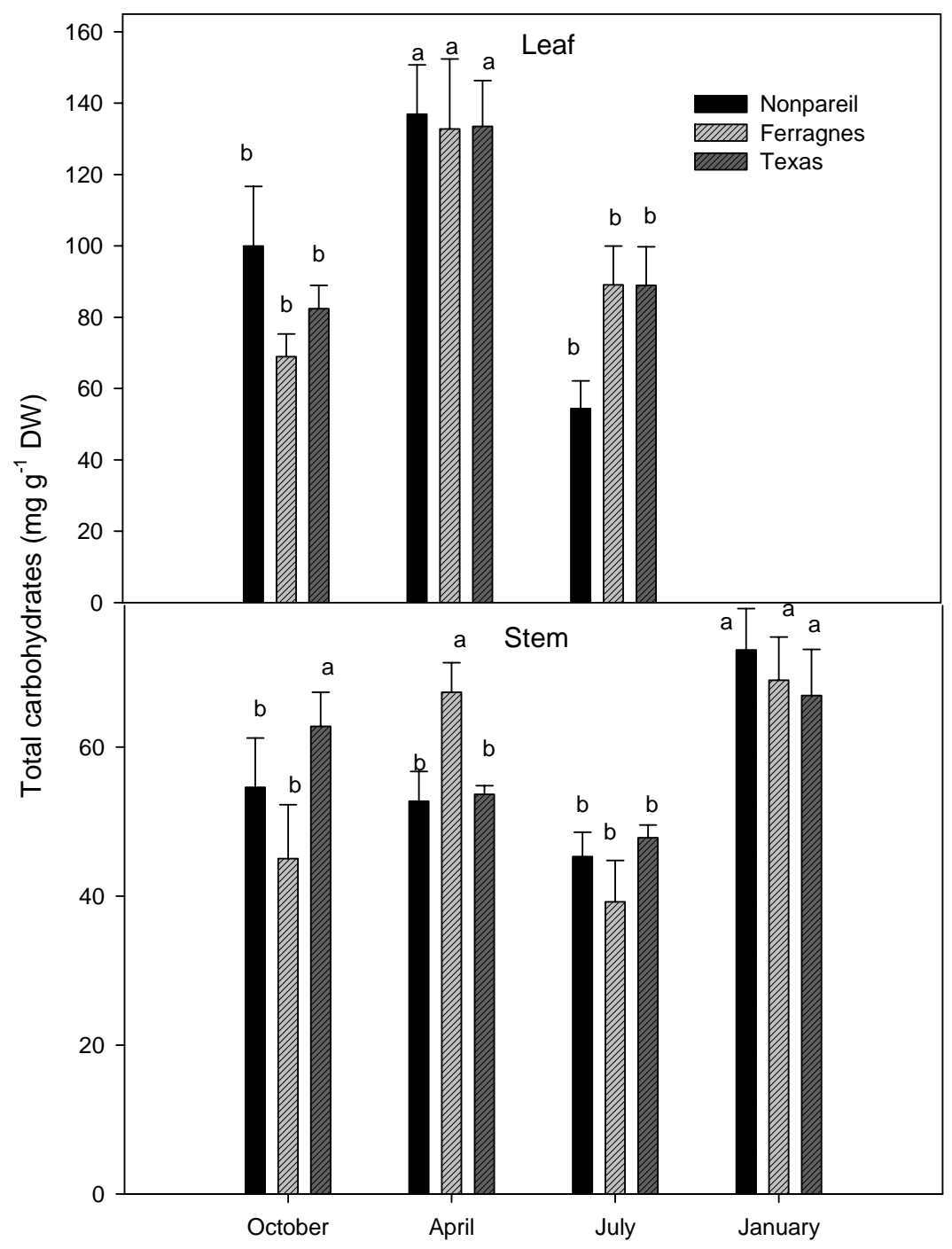

Fig. 1. Seasonal changes of total carbohydrate content in leaves and stems of three varieties (Nonpareil, Ferragnes and Texas) of almond (DW = dry weight). (Vertical bars represent standard error of average of three replications. Data followed by different letters are significantly different from each other $(\mathrm{p}<$ $0.05)$ according to Duncan's test).

leaves of Nonpareil was found in July, and Ferragnes and Texas in October. The lowest carbohydrate content in the stem of these varieties was found in July (Fig. 1). The fact that higher carbohydrate content in the leaves in April may be associated with photosynthetic capacity, leaf surface area and environmental conditions. Higher glucose, fructose and sucrose levels in plant might play a role in adaptation to winter and the concentrations were lower during active growing periods, namely, summer (Pakonen et al. 1991, Stewart and Bannister 1973). In stem cuttings of apple varieties total carbohydrate contents increased in the middle of winter and decreased in spring (Sivaci 2006). 


\section{Acknowledgements}

This study was supported by Adiyaman University Scientific Research Projects Unit (SRP). The authors would like to thank Hüseyin Bereket from Lokman village, who is the grower of the almond varieties in this study, and Dr. Riza Binzet who helped in field studies.

\section{References}

Agunbiade SO and Olanlakun JO 2006. Evaluation of some nutritional characteristics of Indian almond nut. Pakistan J. Nutrit. 5: 316-318.

Dokuzoğuz M and Gülcan R 1973. Researches on breeding of almond genotypes (Prunus amygdalus L.) by the selection in Eagean Region and the in adaptation. Tübitak Toag, Turkey, p. 22.

Ebell, L.F. 1969. Variation in total soluble sugars of conifer tissues with method of analysis. Phytochem. 8: $227-233$.

Esparza G, DeJong TM and Weinbaum SA 2001. Effects of irrigation deprivation during the harvest period on nonstructural carbohydrate and nitrogen contents of dormant, mature almond trees. Tree Physiol. 21: 1081-1086.

Forshey CG and Elfving DC 1989. The relationship between vegetative growth and fruiting in apple trees. Horticul Rev. 11: 229-287.

Gur A 1985. Rosaceae-deciduous fruit trees. In: Halevy, A.H. (Ed.), Handbook of Flowering, (355-389). Boca Raton, CRC Press.

McCready MR, Guggolz J, Silviera V and Owens SH 1950. Determination of starch and amylose in vegetables. Analytic. Chem. 22: 1156-1158.

Misırlı A and Gülcan R 2000. Almond growing in Turkey, Nucis 9: 3-6.

Pakonen T, Saari E, Laine K, Havas P and Lahdesmaki P 1991. How do seasonal changes in carbohydrate concentrations in tissues of the bilberry (Vaccinium myrtillus L.) reflect carbon resource allocation patterns? Acta Oecol. 12: 249-259.

Sivaci A 2006. Seasonal changes of total carbohydrate contents in three varieties of apple (Malus sylvestris Miller) stem cuttings. Scientia Hort. 109: 234-237.

Stewart CR and Bannister P 1973. Seasonal changes in carbohydrate content of three Vaccinium sp. with particular reference to V. uliginosum and its distribution in the British Isles. Flora 162: 134-155.

(Manuscript received on 22 July, 2013; revised on 27 February, 2014) 